\title{
Thermal properties of nano-SiO2 optimized aluminate cementitious composite $\mathrm{Cu}$ powders
}

\author{
Yu Shi ${ }^{1, a}$, Yi Wang ${ }^{1, b}$, Gaoming Wang ${ }^{1, \mathrm{c}}$, Wei $\mathrm{Li}^{1, \mathrm{~d}}$, Tao $\mathrm{Yu}^{1, \mathrm{e}}$, Chunhua $\mathrm{Lu}^{2, \mathrm{f}}$ \\ ${ }^{1}$ Jiangsu Arit New Materials Co. Ltd., Nanjing 210000, China; \\ ${ }^{2}$ Nanjing Tech University, Nanjing 210009, China; \\ aaritsy@163.com, ${ }^{\mathrm{b}}$ aritwy@163.com, ${ }^{\mathrm{c}}$ aritwgm@163.com, ${ }^{\mathrm{d}}$ aritlw@163.com, ${ }^{\mathrm{e}}$ arityt@163.com, ${ }^{\mathrm{f}}$ shy19 \\ 653@163.com
}

Keywords: renewable energy,thermal properties, nanomaterials.

\begin{abstract}
One of the most accepted thermal storage system of solar thermal power for balancing energyconsiders the use of cementitious/concrete materials. We report the preparation of nano-SiO optimized aluminate cementitious pastes as thermal storage materials with mass fractions of $0,5,10$ and $15 \% \mathrm{Cu}$ powders and the influence of $\mathrm{Cu}$ additives on thermal and mechanical properties of the composite pastes. The specimens were heated at 105 , 350, and $900{ }^{\circ} \mathrm{C}$. When $15 \% \mathrm{Cu}$ powders were added, the properties of the composite pastes were significantly modified at corresponding heat-treatment temperature. This paper also deals with the heat evolution of the composite pastes in the early $48 \mathrm{~h}$, observing the double effects of nano- $\mathrm{SiO}_{2}$ and $\mathrm{Cu}$ powders in the hydration process.
\end{abstract}

\section{Introduction}

The increasing demand of energy for recent development of the society is fulfilled by a variety of energy sources. Solar energy as renewable energy offers a promising and viable option for electricity generation for the present and future[1]. Integration of thermal energy storage (TES) technology can facilitate a continuous generation of power from solar thermal power plants[2]. Sensible heat storage material with some advantages including simplicity of design and construction, ease of control and hence lower lost is considered as a promising thermal storage material at high temperature[3].

From the literature[4] it appears that cementitious materials have been widely researched for sensible heat storage applications in solar thermal power plants. Ithas been reported that certain reactions and transformations occur in the cementitious materials with the increasing operating temperature, which influence their thermo-physical properties[5]. Sharper strength loss and cracking are observed when exposed to heat[6]. Nanoparticles are good candidates for improving the mechanical performance of cementitious materials, due to their multiple mechanisms of action, not the least their high pozzolanic activity[7]. Metal $\mathrm{Cu}$ powders has high thermal conductivity of $390 \mathrm{~W} \cdot \mathrm{m}-1 \mathrm{~K}-1$ and volume heat capacity of $3.395 \mathrm{MJ} \cdot \mathrm{m}-3 \cdot \mathrm{K}-1[8]$. The aim of the present work is to investigate the thermal and mechanical performance of nano-SiO2 optimized aluminate cement pastes incorporated with $\mathrm{Cu}$ powders at heat-treatment temperatures of 105,350 , and $900{ }^{\circ} \mathrm{C}$. Therequiredmatrix structure is estimated by addition of nano-SiO2 while the thermal performances is enhanced by addition of $\mathrm{Cu}$ powders.

\section{Materials and specimen preparation}

Aluminate cement performing better corrosion resistance than Portland cement was used as cementing agent. Nano-SiO2 (NS) particles was supplied by Aladdin Reagent Database Inc., China. $\mathrm{Cu}$ powders were used to improve thermal properties of composite materials. High-performance polycarboxylatenumbered for ART-JR2 supplied by Jiangsu Arit New Materials Co. Ltd.in China was used for reducing water consumption and improving the dispersion of the fresh paste.

The composite pastes were all mixed with $1 \mathrm{wt} \%$ NS. A reference paste named 0CS, without $\mathrm{Cu}$ powder, was also prepared.The four mix designs are designated as 0CS, 5CS, 10CS, and 15CS representingNS optimized cement pastes incorporating $\mathrm{Cu}$ powders with mass fractions of $0 \%, 5 \%$, 
$10 \%$, and $15 \%$, respectively. The water to binder ratio was uniformly set at 0.22 . The pastes cast for volume heat capacity (thermal conductivity)andthermal expansion coefficient were performed with moulds of $48 \mathrm{~mm} \times 20 \mathrm{~mm} \times 80 \mathrm{~mm}$ and $5 \mathrm{~mm} \times 5 \mathrm{~mm} \times 50 \mathrm{~mm}$, respectively. The moulds were covered with plastic wrap in order to limit the water evaporation and moistened for $24 \mathrm{~h}$. Then the specimens were demoulded and cured inwater at the temperature of $25{ }^{\circ} \mathrm{C}$ for 7 days. Then the specimens wereseparately exposed to 105,350 , and $900^{\circ} \mathrm{C}$ for $6 \mathrm{~h}$. Comparison of the results about thermal propertiesat these three temperatures was listed in the present paper.

\section{Characterization methods}

Thermal conductivity and volume heat capacity were measured by thermal conductivity constant tester (TPS2500, Hot Disk Ltd., Sweden) with Probe 5465 at $25^{\circ} \mathrm{C}$, and thermal expansion coefficient was measured by thermal expansion coefficient apparatus (RPZ-03P, Institute of refractories Luoyang, China) at a heating rate of $5{ }^{\circ} \mathrm{C} \cdot \min -1$. In this method, $4 \mathrm{~g}$ cement powder or mixture powder was placed in the calorimetric cell, and $2 \mathrm{~g}$ of deionized water was poured into a solution cell.

\section{Thermal properties}

Thermal conductivityof NS optimized pastes incorporated with $\mathrm{Cu}$ powders after heat-treatment at different temperatures are shown in Table 1. It demonstrated that the thermal conductivitysignificantly increased with the increasing $\mathrm{Cu}$ powders contents. The optimal thermal conductivity values were obtained at $\mathrm{Cu}$ powders content of $15 \%$, which showed $52 \%, 11 \%$, and $12 \%$ higher than that of pure paste at $105,350,900{ }^{\circ} \mathrm{C}$, respectively. At the same time, the rise of heat-treatment temperature also would decrease the thermal conductivity.

Table1.Thermal conductivity of NS optimized pastesincorporated withCu powders at different heat-treatment

\begin{tabular}{cccc}
\multicolumn{4}{c}{ temperatures $\left(\mathrm{W} \cdot \mathrm{m}^{-1} \cdot \mathrm{K}^{-1}\right)$} \\
\hline Sign & $105^{\circ} \mathrm{C}$ & $350^{\circ} \mathrm{C}$ & $900^{\circ} \mathrm{C}$ \\
\hline $0 \mathrm{CS}$ & 0.982 & 0.886 & 0.856 \\
$5 \mathrm{CS}$ & 0.991 & 0.969 & 0.902 \\
$10 \mathrm{CS}$ & 1.386 & 0.976 & 0.956 \\
$15 \mathrm{CS}$ & 1.492 & 0.985 & 0.962 \\
\hline
\end{tabular}

Volume heat capacity of NS optimized pastes incorporated with $\mathrm{Cu}$ powders at different heat-treatment temperaturesare shown in Table 2.It indicated that the volume heat capacity increased with the addition of $\mathrm{Cu}$ powders contents and decreased with the elevated temperature. After heating at $105{ }^{\circ} \mathrm{C}$, the volume heat capacity value of the pastes incorporating with $15 \% \mathrm{Cu}$ powders increased to $2.268 \mathrm{MJ} \cdot \mathrm{m}-3 \cdot \mathrm{K}-1$, which was $10 \%$ higher than that of pure paste. Then further increasing heat-treatment to $350{ }^{\circ} \mathrm{C}$, the volume heat capacity of the pastes decreased compared with the pastes heated at $105^{\circ} \mathrm{C}$. Even so, the highest volume heat capacity of the pastes composite $15 \% \mathrm{Cu}$ powders at $350{ }^{\circ} \mathrm{C}$ still exhibited $17 \%$ higher than that of pure paste. Afterwards, the volume heat capacity of the pastes composite $15 \% \mathrm{Cu}$ powders after heat-treatment at $900{ }^{\circ} \mathrm{C}$ was $21 \%$ higher than that of pure paste.

Table2. Volume heat capacity of NS optimized pastes incorporated with Cu powders at different heat-treatment

\begin{tabular}{lccc}
\multicolumn{4}{c}{ temperatures $\left({\left.\mathrm{MJ} \cdot \mathrm{m}^{-3} \cdot \mathrm{K}^{-1}\right)}\right.$ ) } \\
\hline Sign & $105^{\circ} \mathrm{C}$ & $350^{\circ} \mathrm{C}$ & $900^{\circ} \mathrm{C}$ \\
\hline 0CS & 2.057 & 1.676 & 1.476 \\
5CS & 2.133 & 1.772 & 1.569 \\
$10 \mathrm{CS}$ & 2.204 & 1.846 & 1.677 \\
$15 \mathrm{CS}$ & 2.268 & 1.965 & 1.782 \\
\hline
\end{tabular}

The thermal expansion coefficient curves of NS optimized pastes incorporated with Cu powders at elevated temperature are shown in Figure1.The measurement temperature ranges from 100 to $900{ }^{\circ} \mathrm{C}$. The results were obtained after preheating at $900{ }^{\circ} \mathrm{C}$ for $6 \mathrm{~h}$. It can be noted that when the temperature was up to $400{ }^{\circ} \mathrm{C}$ thermal expansion coefficient showed a largely fluctuation. Then the specimens still could keep stable ranging from 500 to $900{ }^{\circ} \mathrm{C}$. 


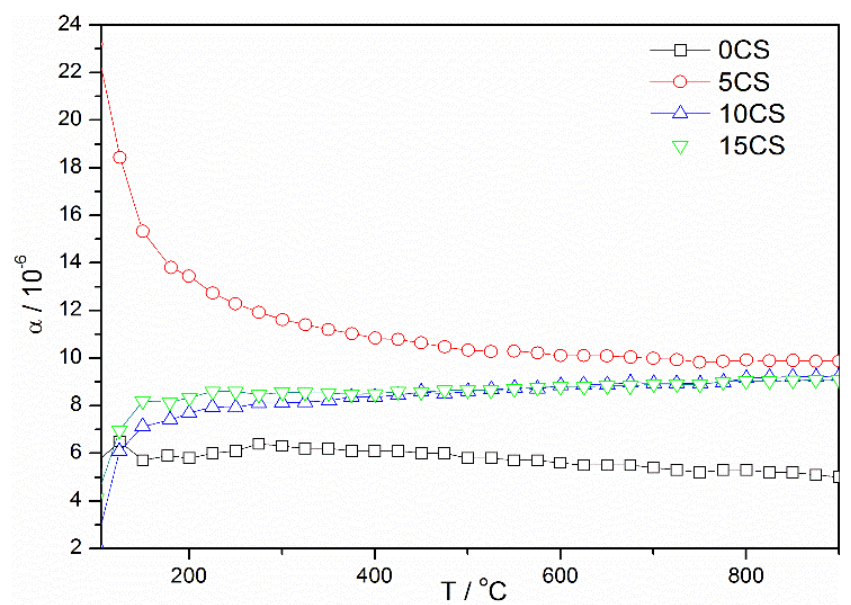

Figure1. Thermal expansion coefficient curves of NS optimized pastes incorporated with Cu powders at elevated temperature

\section{Conclusions}

In this work, we investigate the thermal and mechanical properties of nano-SiO2 optimized pastes incorporated with $\mathrm{Cu}$ powders. $\mathrm{Cu}$ powders obviously retard the solid phase formation in the acceleration period. In the heating process, $\mathrm{Cu}$ powders are gradually oxidized toCuO, decreasing the mass loss of the composite paste. It is desirable that at corresponding temperature nano-SiO2 optimized aluminate cementitious storage materials composite metal $\mathrm{Cu}$ powders have better thermal properties. On the other hand, the compressive strength still can meet the requirement of thermal storage materials. Consequently, nano-SiO2based aluminate cementitiouscomposite material incorporated withCu powders is available for the further development of thermal storage materials.

\section{References}

[1] Paddy Finn, Colin Fitzpatrick. Demand side management of industrial electricity consumption: Promoting the use of renewable energy through real-time pricing. Applied Energy 113(2014): $11-21$.

[2] V. Sivareddy, S.C.Kaushik, K.R.Ranjan, et al. State-of-the-artofsolarthermalpowerplants-A review. Renewable and Sustainable Energy Reviews 27(2013): 258-273.

[3] S. Khare, M.Dell'amico, S.Mcgarry C.Knight. Selection of materials for high temperature sensible energy storage. Solar Energy Materials \& Solar Cells 115(2013): 114 - 122.

[4] A. J. N. Khalifa, E. F. Abbas. A comparative performance study of some thermal storage materials used for solar space heating. Energy and Buildings 41(2009): 407-415.

[5] Y.L. Bruni, L.B. Garrido, E.F. Aglietti. Reaction and phases from monoclinic zirconia and calcium aluminate cement at high temperatures. Ceramics International 38(2012): 4237-4244.

[6] D. Laing, D. Lehmann, M. Fiss, et al. Test results of concrete thermal energy storage for parabolic trough power plants. Journal of Solar Energy Engineering-Transactions of the Asme 131(2009): 041007( 041006 pages).

[7] Huiwen Yuan, Chunhua Lu, Zhongzi Xu, et al. Mechanical and thermal properties of cement composite graphite for solar thermal storage materials. Solar energy 86(2012): 3227-3233.

[8] Dalun Ye and Jianhua Hu. The Handbook of Practical Inorganic Thermodynamic Data. Beijing (2002): Metallurgic Industry Pres. 